\title{
Sterilization protocols and the effect of plant growth regulators on callus induction and secondary metabolites production in in vitro cultures Melia azedarach L.
}

\author{
Fatemeh Ahmadpoor, Nasser Zare* ${ }^{*}$, Rasool Asghari and Parisa Sheikhzadeh
}

\begin{abstract}
Melia azedarach L. is a valuable source of antioxidants and secondary metabolites. This study is a first extensive report about the effect of different serialization protocols and plant growth regulators (PGRs) on explant disinfection efficiency, callus induction and secondary metabolites production and accumulation in callus cultures of M. azedarach L. In this regard, the effect of plant growth regulators on callus induction and secondary metabolites production were examined. In addition, different sterilization agents were evaluated for disinfection of chinaberry leaf explants. The results showed that the lowest percentage of explant contamination and browning with the highest percentage of callus induction and callus growth obtained with explants pretreated with benomyl $(2 \mathrm{~g} / \mathrm{L})$ for $2 \mathrm{~h}$ and sterilized with $7 \% \mathrm{H}_{2} \mathrm{O}_{2}$ for $10 \mathrm{~min}$ and $\mathrm{NaOCl} 2 \%$ (without pH adjustment) for $12 \mathrm{~min}$. Although adjusting the $\mathrm{pH}$ of $\mathrm{NaOCl}$ to $\mathrm{pH}$ $=7$ and 10 significantly reduced the microbial contamination and increased the percentage of contamination-free cultures of M. azedarach L., adversely influenced the explant viability and callus induction and growth. The highest percentage of callus induction obtained on the MS medium containing $3 \mathrm{mg} / \mathrm{L} \mathrm{NAA} / 2,4-\mathrm{D}$ and 1 or $3 \mathrm{mg} / \mathrm{L} \mathrm{Kin/}$ BAP, and the highest callus yield (1804.833 mg/explant) belonged to the MS medium supplemented with $5 \mathrm{mg} / \mathrm{L}$ 2,4-D and $5 \mathrm{mg} / \mathrm{L} \mathrm{Kin}$. The callus cultures grown on the MS medium supplemented with $3 \mathrm{mg} / \mathrm{L} \mathrm{NAA}$ and $1 \mathrm{mg} / \mathrm{L}$ Kin produced the highest amount of Quercetin ( $2.06 \mathrm{mg} / \mathrm{g}$ fresh weight), Rutin (5.56 mg/g fresh weight) and Kaempferol (1.84 mg/g fresh weight).
\end{abstract}

Keywords: Disinfection, Hydrogen peroxide, Kaempferol, Melia azedarach L., Quercetin, Rutin

\section{Introduction}

Melia azedarach L. (known as Chinaberry) is one of the most valuable pharmaceutical plants. It has therapeutic properties such as antihyperglycemic, anticarcinogenic, anti-inflammatory, antiviral, insecticidal and antioxidant effects. A large numbers of secondary metabolites such as alkaloids, phenolic compounds, and vitamins have been recognized in M. azedarach L. (Yalla et al. 2021;

\footnotetext{
*Correspondence: zarenasser@yahoo.com

Department of Plant Production and Genetics, Faculty of Agriculture and Natural Resources, University of Mohaghegh Ardabili, P.O. Box 179, Ardabil, Iran
}

Coria et al. 2008). The success of a plant tissue culture relies on many factors, such as culture medium composition, particularly plant growth regulators (PGRs), age and other physiological aspects of donor plant (Zare et al. 2009; Asghari Zakaria et al. 2011).

In vitro fungal and bacterial contaminations are also one of the most important limiting factors, particularly in woody plants. In order to overcome fungal and bacterial contaminations in the disinfection stage, different surface sterilizing agents including sodium and calcium hypochlorite, ethanol, mercuric chloride, 
silver nitrate, antibiotics, and fungicide were used in laboratories worldwide. Nevertheless, the efficiency of these treatments is low in woody plants, or some of them are very toxic to plant tissues. Furthermore, the efficiency of sterilization methods depends on different parameters, such as the physiological state of the mother plant, the size, age and type of the explant, the type and concentration of sterilization agent, and exposure duration (Teixeira da Silva et al. 2015). So, it is difficult to present a standard disinfection protocol for all plant species and explants. Therefore, the sterilization procedure should be optimized for any species to gain the maximum sterilized viable explants. Assareh and Sardabi (2005) reported that among calcium and sodium hypochlorite and mercuric chloride agents used for surface sterilization of Ziziphus spina-christi explants, $\mathrm{Ca}(\mathrm{OCl})_{2}(5 \%$ for $20 \mathrm{~min})$ was the most efficient in explants sterilization. In contrast, in Ghaffoor et al. (2003) studies, $\mathrm{NaOCl}$ was found to be efficient for removing the contaminations in Solanum tuberosum L. The reports on tissue culture of woody plants indicate that surface disinfection was not efficient to produce clean cultures, and always is accompanied with a high level of bacterial and fungal contamination (Pence 2005).

Biotechnological techniques, especially plant cell and tissue culture, play an essential role in exploring alternative approaches for the production of desirable therapeutic compounds from plants (Farjaminezhad et al. 2013) and environmental adaptation (Farjaminezhad and Garoosi 2021). The callus induction and establishment of suspension cultures are two basic techniques, which have been used for production of wide range of phytochemicals, including therapeutic and antioxidant compounds (Colgecen et al. 2011). Flavonoids are a large group of phenolic compounds, which are generally found in nearly all plant species. Flavonoids are known as potential metal chelators and antioxidants. Several therapeutic and disease inhibition properties of flavonoids have been reported by researchers, which make them interesting nutraceuticals in human nutrition and healthcare (Prochazkova et al. 2011). There are reports about the production of flavonoids using different biotechnological methods, including callus and cell suspension cultures (Haida et al. 2019). So, the present study was aimed to the optimize the sterilization method for $M$. azedarach L. leaf explants using different sterilization agents such as $\mathrm{H}_{2} \mathrm{O}_{2}$ and $\mathrm{NaOCl}$, and $\mathrm{pH}$ adjustment of $\mathrm{NaOCl}$. Moreover, the effects of different factors on callus induction from leaf explants of $M$. azedarach $\mathrm{L}$. and production of secondary metabolites including rutin, quercetin and kaempferol in callus cultures was investigated.

\section{Materials and methods \\ Explant preparation and sterilization}

In this study, young leaves of Chinaberry ( $M$. azedarach L.) were prepared from the Qazvin province $\left[36^{\circ} 19^{\prime}\right.$

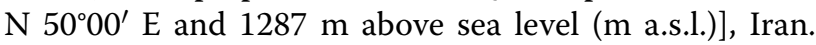
The young leaves were pretreated with a soft commercial detergent and washed for $30 \mathrm{~min}$. The leaf explants were sterilized using different protocols as described below.

\section{Experiment 1: the effects of different concentrations of $\mathrm{H}_{2} \mathrm{O}_{2}$ and $\mathrm{NaOCl}$, and $\mathrm{pH}$ adjustment of $\mathrm{NaOCl}$ on the sterilization and growth of explants}

The leaf explants were dipped in benomyl $\left(\mathrm{C}_{14} \mathrm{H}_{18} \mathrm{~N}_{4} \mathrm{O}_{3}\right)$ (a systemic fungicide) solution $(3 \mathrm{~g} / \mathrm{L})$ for $2 \mathrm{~h}$, and then treated with $5 \%$ or $7 \%(\mathrm{v} / \mathrm{v}) \mathrm{H}_{2} \mathrm{O}_{2}$ for 10 or $15 \mathrm{~min}$, then soaked in $70 \%(\mathrm{v} / \mathrm{v})$ ethanol for $20 \mathrm{~s}$, and finally soaked in $2 \%(\mathrm{w} / \mathrm{v}) \mathrm{NaOCl}$ with different $\mathrm{pH}(\mathrm{pH}=7$ or 10 or without $\mathrm{pH}$ adjustment) containing 2 drops of Tween20 for 12 min (Additional file 1: Table S1). After that, the leaves were rinsed with sterile distilled water (SDW) for three times and then sliced into small fragments $(0.5 \mathrm{~cm}$ squares), and cultured on MS (Murashige and Skoog 1962) medium supplemented with different concentrations of auxins [ $\alpha$-naphthalene acetic acid (NAA) or 2,4-Dichlorophenoxyacetic acid (2,4-D) at 3 and $5 \mathrm{mg} / \mathrm{L}$ concentrations] and cytokinins [6-benzylaminopurine (BAP) or Kinetin (Kin) at 1, 3 and $5 \mathrm{mg} / \mathrm{L}$ concentrations].

Common disinfection method including sterilization with $70 \%(\mathrm{v} / \mathrm{v})$ ethanol for $20 \mathrm{~s}+2 \%(\mathrm{w} / \mathrm{v}) \mathrm{NaOCl}$ without $\mathrm{pH}$ adjustment for $12 \mathrm{~min}$ considered as control (Additional file 1: Table S1).

\section{Experiment 2: the effect of benomyl inclusion in culture} medium on the contaminations and growth of the explants The leaf explants were surface sterilized using $5 \%(\mathrm{v} / \mathrm{v})$ $\mathrm{H}_{2} \mathrm{O}_{2}$ for $10 \mathrm{~min}, 70 \%(\mathrm{v} / \mathrm{v})$ ethanol for $20 \mathrm{~s}$ and $2 \%$ $(\mathrm{w} / \mathrm{v}) \mathrm{NaOCl}$ with different $\mathrm{pH}[\mathrm{pH}=10$ or without $\mathrm{pH}$ adjustment $(\mathrm{pH} \geq 12)$ ] plus Tween-20 for $12 \mathrm{~min}$ (Additional file 1: Table S2). Finally, the leaves were rinsed with distilled water for three times and then sliced into small fragments $(0.5 \mathrm{~cm}$ squares $)$ and cultured on the MS medium supplemented with $1 \mathrm{mg} / \mathrm{L}$ NAA or 2,4-D + $1 \mathrm{mg} / \mathrm{L}$ BAP or Kin and benomyl fungicide $(100$ or $500 \mathrm{mg} / \mathrm{L})$.

Common disinfection method [including 70\% (v/v) ethanol for $20 \mathrm{~s}+2 \%(\mathrm{w} / \mathrm{v}) \mathrm{NaOCl}$ without $\mathrm{pH}$ adjustment for $12 \mathrm{~min}$ ] was considered as control (Additional file 1: Table S2). 


\section{Medium preparation and cultures incubation condition}

MS medium were supplemented with $3 \%$ sucrose and solidified using $0.8 \%$ plant agar. The $\mathrm{pH}$ of the medium was adjusted to $5.7-5.8$ before autoclaving at $121^{\circ} \mathrm{C}$ for $20 \mathrm{~min}$. Cultures were maintained in a growth chamber at $24 \pm 1{ }^{\circ} \mathrm{C}$ and 16-h photoperiod (cool Wight florescent light; $55 \mu \mathrm{mol} / \mathrm{m}^{2}$ s) and sub-cultured at monthly intervals. The percentage of callus induction, bacterial and fungal contaminations, viable and browning explants was recorded 4 weeks after culture. The callus fresh weight ( $\mathrm{mg} /$ single explant) was measured 3 months after culture.

\section{Secondary metabolites analysis}

According to the results of the experiments 1 and 2, the leaf explants were surface sterilized using $\mathrm{A}_{2}$ sterilization method, and cultured on the MS medium containing different combinations of plant growth regulators (PGRs) for callus induction and growth. The cultures were maintained in above maintained conditions and sub-cultured at 4 weeks interval. The secondary metabolites of the calli derived from leaf explants were extracted using Wagner (1979) method. Briefly, $0.1 \mathrm{~g}$ of fresh callus pulverized with liquid nitrogen, and suspended in $5 \mathrm{~mL}$ acidified methanol (methanol 99:1 acetic acid). The samples were incubated at room temperature for $72 \mathrm{~h}$ and centrifuged at $4000 \mathrm{rpm}$ for $10 \mathrm{~min}$. The supernatant was collected and used for determination of total phenolic, flavonoids and anthocyanin content.

Total phenolic content (TPC) were measured using colorimetric Folin-Ciocalteu spectrophotometric method described by Al-Farsi et al. (2005) and quantified using the standard curve of gallic acid (Sigma) $(0,0.001,0.0015$, 0.002 and $0.003 \mathrm{~g} / \mathrm{L}$ of methanol $)(\mathrm{y}=14.333 \mathrm{x}-0.00003$ and $\left.\mathrm{R}^{2}=0.9933\right)$. Briefly, $3 \mathrm{~mL}$ of diluted Folin-Ciocalteu (1:10 with deionized water) were added to the $400 \mu \mathrm{L}$ extract and incubated for $5 \mathrm{~min}$ in a water bath at $22^{\circ} \mathrm{C}$. Then, $3 \mathrm{~mL}$ sodium bicarbonate solution (7\%) was added and the samples were incubated at $22{ }^{\circ} \mathrm{C}$ for $90 \mathrm{~min}$. The absorbance of the samples were recorded at $725 \mathrm{~nm}$ using a spectrophotometer (SmartSpec Plus spectrophotometer, Bio-Rad, Hercules, CA, USA). Total phenolic content of the callus cells was expressed as $\mathrm{mg}$ of gallic acid equivalents (GAE) per $1 \mathrm{~g}$ fresh weight (FW). TPC calculated using equation 1 (Shubhangi et al. 2017):

$$
\mathrm{T}=(\mathrm{C} \times \mathrm{V}) / \mathrm{M}
$$

where $\mathrm{T}$ is total phenolic content (mg GAE/g FW), C is the concentration of total phenolic content (TPC) (mg/ $\mathrm{mL}), \mathrm{V}$ is the final volume of the extract $(\mathrm{mL})$, and $\mathrm{M}$ is the fresh weight of callus sample (g).

The total flavonoid content (TFC) in the callus cultures was determined using an aluminum chloride $\left(\mathrm{AlCl}_{3}\right)$ colorimetric method reported by Anjum et al. (2017). Briefly, $0.25 \mathrm{~mL}$ of $10 \% \mathrm{AlCl}_{3}$ and $0.25 \mathrm{~mL}$ of $1 \mathrm{M}$ potassium acetate $\left(\mathrm{CH}_{3} \mathrm{COOK}\right)$ were added to $1 \mathrm{~mL}$ of methanolic extract. Then, the absorbance of the mixture was measured immediately at $498 \mathrm{~nm}$ against the control sample containing acidified methanol instead of the callus extract. The standard curve was prepared using different concentrations $(0,0.4,0.8,1.6$, and $2.4 \mathrm{~g} / \mathrm{L})$ of quercetin in methanol and used for quantification of TFC in the callus samples $\left(y=0.0573 x+0.0025, R^{2}=0.9888\right)$. The TFC of the callus expressed as mg of quercetin equivalents/ $1 \mathrm{~g} F W$ using the equation 1 , where $C$ is the concentration of flavonoid $(\mathrm{mg} / \mathrm{mL}), \mathrm{V}$ is the final volume of extract $(\mathrm{mL})$, and $\mathrm{M}$ is the weight of the sample $(\mathrm{g} F W)$.

In order to quantification of anthocyanin content, the absorbance of the extracts measured at $550 \mathrm{~nm}$. Then, the concentration of anthocyanin was calculated using the formula $\mathrm{A}=\varepsilon \mathrm{bc}$ and molar extinction coefficient $\left(\varepsilon_{550}=33,000 \times 10^{6} \mathrm{M}^{-1} \mathrm{~cm}^{-1}\right)$, and expressed as $\mu \mathrm{M} / \mathrm{g}$ FW. Where A is the absorbance of the extracts, $\mathrm{b}$ is the width of the cuvette $(\mathrm{cm})$, and $\mathrm{c}$ is the concentration of anthocyanin $(\mathrm{M})$.

\section{HPLC analysis of rutin, quercetin and kaempferol}

The separation, determination, and quantification of rutin, quercetin and kaempferol performed using highperformance liquid chromatography (HPLC) analysis. The secondary metabolites of the calli were extracted using $\mathrm{Zu}$ et al. (2006) method. Briefly, $0.5 \mathrm{~g}$ of the fresh callus pulverized in liquid nitrogen, and $1.5 \mathrm{~mL}$ ethanol $(90 \% \mathrm{v} / \mathrm{v})$ were added and vortexed for 5-10 $\mathrm{min}$. Then, the samples were sonicated in a bath sonicator (Bandelin electronic ${ }^{\circledR}$, Germany) for $15 \mathrm{~min}$ at $35{ }^{\circ} \mathrm{C}$ and incubated at room temperature for $3 \mathrm{~h}$. The vortex and sonication were repeated twice. Finally, the samples were centrifuged (Sigma 1-14 K, Germany) at 10,000 rpm for $15 \mathrm{~min}$. The supernatant was collected and filtered using a $0.22 \mu \mathrm{m}$ filter. The filtrate was dried at $45{ }^{\circ} \mathrm{C}$, till final volume was up to $100 \mu \mathrm{L}$ and stored at $-20{ }^{\circ} \mathrm{C}$ until analysis. The standard curve was prepared using different concentrations of rutin (Sigma-Aldrich, USA) (5, 50, $100 \mathrm{ppm}$ ); quercetin (Sigma-Aldrich, Q4951, CAS: 117-39-5) and kaempferol (Sigma-Aldrich, 60010, CAS: 520-18-3) (5, 50, 100 and $500 \mathrm{ppm})$ and used for quantification in the callus samples.

HPLC analyses were performed on a Sykam HPLC system (SYKAM 1130, Sykam GmbH, Germany). HPLC separations carried out on a HIQ SIL C18V reversedphase column (ø $4.6 \times 250 \mathrm{~mm})$ packed with $5 \mu \mathrm{m}$ diameter particles, the mobile phase was methanolacetonitrile-water $(40: 15: 45, \mathrm{v} / \mathrm{v} / \mathrm{v})$. Rutin, quercetin and kaempferol were detected by diode-array detector 
DAD following HPLC separation at $257 \mathrm{~nm}$ for rutin and $368 \mathrm{~nm}$ for quercetin and kaempferol. Flow rate and injection volume was $1.0 \mathrm{~mL} / \mathrm{min}$ and $20 \mu \mathrm{L}$, respectively. All chromatographic operations were carried out at room temperature.

\section{Statistical analysis}

Disinfection experiments conducted in a factorial (disinfection and PGRs as factors) arrangement based on a completely randomized design with six replicates with 12 explants per replication. Secondary metabolites (TPC, $\mathrm{TFC}, \mathrm{AC}$, rutin, quercetin and kaempferol) measurements carried out in a completely randomized design (CRD) with three replications. Experimental data subjected to analysis of variance (ANOVA) $(p<0.05)$ and mean comparison using Duncan's Multiple Range Test (DMRT) (at $\mathrm{p}<0.05)$ using IBM SPSS Ver.21 statistical software (IBM Corporation and Others, Armonk, NY, USA). The results expressed as mean \pm SE. The graphs produced using Microsoft Office Excel 2010.

\section{Results \\ Disinfection \\ Experiment 1: the effects of different concentrations of $\mathrm{H} 2 \mathrm{O} 2$ and $\mathrm{NaOCl}$, and $\mathrm{pH}$ adjustment of $\mathrm{NaOCl}$ on the contamination and growth of explants}

Some of the cultures were contamination-free and the explants exhibited rapid swelling and cell proliferation especially from the edge of cuttings, which was led to the callus formation within 2-3 weeks (Additional file 1: Fig. S1). Embryogenic calli had green spots that showed signs of differentiation and morphogenesis after culture on the medium containing high proportion of cytokinin/auxin (Additional file 1: Fig. S2). The results indicated that the percentage of bacterial and fungal contamination, clean explants, explants viability and browning and callus induction and growth were significantly influenced by disinfection methods. Furthermore, there were significant differences between PGRs treatments in terms of explants viability and browning (\%), and callus induction and growth (Additional file 1: Table S3). The highest bacterial (15.97\%) and fungal (29.49\%) contaminations occurred in the control sterilization method. The highest percentage of clean explants was achieved in the $A_{3}-A_{7}$ disinfection methods, while the highest percentage of viable explants was obtained in the control, $\mathrm{A}_{1}, \mathrm{~A}_{2}$ and $\mathrm{A}_{5}$ disinfection methods (Table 1). Furthermore, the lowest percentage of explant browning and the highest percentage of callus induction and growth achieved with the $\mathrm{A}_{2}$ disinfection method (Table 1). As shown in Table 1, in the methods including $\mathrm{NaOCl} \mathrm{pH}$ adjustment $\left(\mathrm{A}_{3}, \mathrm{~A}_{5}\right.$ and $A_{7}$ ) the minimum percentage of explants with fungal and bacterial contamination was occurred, but the percentage of explants with callus induction and growth response was also lower. For instance, the application of $2 \% \mathrm{NaOCl}$ with $\mathrm{pH}=7$ for $12 \min \left(\operatorname{method} \mathrm{A}_{3}\right)$ significantly decreased the explant viability and increased the browning explants as compared to $2 \% \mathrm{NaOCl}$ without $\mathrm{pH}$ adjustment (method $\mathrm{A}_{2}$ ). Furthermore, the methods $A_{2}$ and $A_{3}$ in which employed benomyl pretreatment and $\mathrm{H}_{2} \mathrm{O}_{2}$ had an inhibitory effect on the bacterial contamination compared to the method $\mathrm{A}_{1}$ in which only explants pretreated with benomyl solution $(3 \mathrm{mg} / \mathrm{L})$ for $2 \mathrm{~h}$ (Table 1). Furthermore, the highest percentage of callus induction was obtained in MS medium supplemented with $3 \mathrm{mg} / \mathrm{L} \mathrm{NAA}+1 \mathrm{mg} / \mathrm{L}$ Kin or BAP and $3 \mathrm{mg} / \mathrm{L}$ NAA or $2,4-\mathrm{D}+3 \mathrm{mg} / \mathrm{L}$ BAP (Table 2). While, the highest callus yield (fresh weight) was obtained in the MS medium containing $5 \mathrm{mg} / \mathrm{L} 2,4-\mathrm{D}+5 \mathrm{mg} / \mathrm{L}$ Kin and $5 \mathrm{mg} / \mathrm{L} \mathrm{NAA}+5 \mathrm{mg} / \mathrm{L}$ BAP (Table 2 ).

Table 1 The effect of different disinfection methods on the percentage of microbial contamination and in vitro response of $M$. azedarach L. leaf explants

\begin{tabular}{lllllrrr}
\hline $\begin{array}{l}\text { Methods of } \\
\text { disinfection }\end{array}$ & $\begin{array}{l}\text { Bacterial } \\
\text { contamination } \\
(\%)\end{array}$ & $\begin{array}{l}\text { Fungal } \\
\text { contamination } \\
\text { (\%) }\end{array}$ & Clean explant (\%) & Viability (\%) & Browning (\%) & Callus induction (\%) & $\begin{array}{l}\text { weight of callus (mg/ } \\
\text { explant) }\end{array}$ \\
\hline Control & $15.97 \pm 3.10^{\mathrm{d}}$ & $29.49 \pm 4.08^{\mathrm{c}}$ & $54.5 \pm 4.8^{\mathrm{d}}$ & $1.00 \pm 0.00^{\mathrm{a}}$ & $0.00 \pm 0.00^{\mathrm{a}}$ & $26.78 \pm 5.58^{\mathrm{b}}$ & $873.733 \pm 34.418^{\mathrm{ab}}$ \\
$\mathrm{A}_{1}$ & $8.74 \pm 1.56^{\mathrm{c}}$ & $1.08 \pm 0.45^{\mathrm{a}}$ & $90.2 \pm 1.6^{\mathrm{bc}}$ & $1.00 \pm 0.00^{\mathrm{a}}$ & $0.00 \pm 0.00^{\mathrm{a}}$ & $5.91 \pm 1.59^{\mathrm{c}}$ & $484.568 \pm 26.896^{\mathrm{bc}}$ \\
$\mathrm{A}_{2}$ & $5.57 \pm 1.21^{\mathrm{bc}}$ & $7.45 \pm 1.47^{\mathrm{b}}$ & $87.0 \pm 2.4^{\mathrm{c}}$ & $99.65 \pm 0.35^{\mathrm{a}}$ & $0.35 \pm 0.35^{\mathrm{a}}$ & $38.56 \pm 5.49^{\mathrm{a}}$ & $1191.294 \pm 37.148^{\mathrm{a}}$ \\
$\mathrm{A}_{3}$ & $3.39 \pm 0.94^{\mathrm{b}}$ & $0.00 \pm 0.00^{\mathrm{a}}$ & $96.6 \pm 0.9^{\mathrm{ab}}$ & $86.45 \pm 3.29^{\mathrm{b}}$ & $14.20 \pm 3.25^{\mathrm{b}}$ & $1.52 \pm 0.91^{\mathrm{c}}$ & $158.921 \pm 96.003^{\mathrm{c}}$ \\
$\mathrm{A}_{4}$ & $0.40 \pm 0.40^{\mathrm{a}}$ & $0.00 \pm 0.00^{\mathrm{a}}$ & $99.6 \pm 0.4^{\mathrm{a}}$ & $79.25 \pm 3.58^{\mathrm{c}}$ & $21.14 \pm 3.67^{\mathrm{c}}$ & $9.41 \pm 2.37^{\mathrm{c}}$ & $554.056 \pm 89.829^{\mathrm{bc}}$ \\
$\mathrm{A}_{5}$ & $0.86 \pm 0.60^{\mathrm{a}}$ & $0.69 \pm 0.48^{\mathrm{a}}$ & $98.5 \pm 0.8^{\mathrm{a}}$ & $99.31 \pm 0.48^{\mathrm{a}}$ & $0.79 \pm 0.55^{\mathrm{a}}$ & $10.77 \pm 2.82^{\mathrm{c}}$ & $282.111 \pm 100.367^{\mathrm{c}}$ \\
$\mathrm{A}_{6}$ & $1.06 \pm 0.60^{\mathrm{a}}$ & $1.32 \pm 0.63^{\mathrm{a}}$ & $97.6 \pm 0.8^{\mathrm{a}}$ & $77.87 \pm 3.94^{\mathrm{c}}$ & $22.72 \pm 4.01^{\mathrm{c}}$ & $3.91 \pm 1.43^{\mathrm{c}}$ & $130.382 \pm 60.386^{\mathrm{c}}$ \\
$\mathrm{A}_{7}$ & $0.37 \pm 0.37^{\mathrm{a}}$ & $0.00 \pm 0.00^{\mathrm{a}}$ & $99.6 \pm 0.4^{\mathrm{a}}$ & $54.48 \pm 4.64^{\mathrm{d}}$ & $45.52 \pm 4.64^{\mathrm{d}}$ & $9.44 \pm 3.76^{\mathrm{c}}$ & $108.147 \pm 47.128^{\mathrm{c}}$ \\
\hline
\end{tabular}

In each column, different letters indicate a significant difference $(P \leq 5 \%)$ according to Duncan's Multiple-Range Tests (DMRTs) 
Table 2 The effect of the different types and concentrations of PGRs on the explant viability, browning, and callus induction from leaf explants of $M$. azedarach $L$.

\begin{tabular}{|c|c|c|c|c|}
\hline $\begin{array}{l}\text { Concentration of PGRs } \\
(\mathrm{mg} / \mathrm{L})\end{array}$ & Viability (\%) & Browning (\%) & Callus induction (\%) & Callus weight (mg/explant) \\
\hline $3 \mathrm{NAA}+1 \mathrm{Kin}$ & $91.33 \pm 4.00^{\mathrm{ab}}$ & $8.67 \pm 4.00^{c d}$ & $18.17 \pm 3.60^{\mathrm{a}}$ & $455.737 \pm 17.445^{\mathrm{b}-\mathrm{e}}$ \\
\hline $3 \mathrm{NAA}+1 \mathrm{BAP}$ & $83.70 \pm 5.98^{b c}$ & $16.30 \pm 0.50^{\mathrm{abc}}$ & $19.00 \pm 3.79^{\mathrm{a}}$ & $814.529 \pm 252.15^{\mathrm{b}-\mathrm{e}}$ \\
\hline $32,4-D+1$ Kin & $88.30 \pm 5.03^{a b}$ & $11.89 \pm 3.18^{\mathrm{bcd}}$ & $15.32 \pm 3.89^{a b}$ & $66.444 \pm 39.585^{\text {de }}$ \\
\hline $32,4-D+1$ BAP & $90.82 \pm 3.50^{a b}$ & $9.17 \pm 3.53^{\mathrm{cd}}$ & $16.00 \pm 3.83^{\mathrm{ab}}$ & $103.150 \pm 41.373^{\text {de }}$ \\
\hline $3 \mathrm{NAA}+3 \mathrm{Kin}$ & $78.80 \pm 6.07^{c}$ & $21.19 \pm 4.07^{\mathrm{a}}$ & $14.49 \pm 3.92^{\mathrm{abc}}$ & $987.000 \pm 28.824^{b c}$ \\
\hline $3 \mathrm{NAA}+3 \mathrm{BAP}$ & $77.66 \pm 6.18^{c}$ & $22.33 \pm 4.18^{\mathrm{a}}$ & $18.35 \pm 3.13^{\mathrm{a}}$ & $851.095 \pm 30.287^{\mathrm{bcd}}$ \\
\hline $32,4-D+3 \mathrm{Kin}$ & $76.80 \pm 5.23^{c}$ & $23.19 \pm 3.43^{\mathrm{a}}$ & $10.14 \pm 3.46^{\mathrm{abc}}$ & $78.800 \pm 48.109^{\mathrm{de}}$ \\
\hline $32,4-D+3$ BAP & $83.21 \pm 5.62^{b c}$ & $18.06 \pm 3.01^{\mathrm{ab}}$ & $20.15 \pm 3.14^{\mathrm{a}}$ & $488.714 \pm 19.267^{\mathrm{b}-\mathrm{e}}$ \\
\hline $5 \mathrm{NAA}+1 \mathrm{Kin}$ & $91.97 \pm 4.18^{\mathrm{ab}}$ & $9.03 \pm 4.18^{\mathrm{cd}}$ & $11.85 \pm 3.69^{\mathrm{abc}}$ & $154.706 \pm 83.611^{\text {de }}$ \\
\hline $5 \mathrm{NAA}+1 \mathrm{BAP}$ & $89.30 \pm 4.07^{\mathrm{ab}}$ & $10.70 \pm 4.07^{\mathrm{bcd}}$ & $3.67 \pm 3.67^{\mathrm{bc}}$ & $53.647 \pm 53.647^{\mathrm{de}}$ \\
\hline $52,4-\mathrm{D}+1 \mathrm{Kin}$ & $91.66 \pm 3.76^{\mathrm{ab}}$ & $8.33 \pm 3.76^{\mathrm{cd}}$ & $0.98 \pm 0.98^{c}$ & $2.765 \pm 2.765^{e}$ \\
\hline $52,4-D+1$ BAP & $91.24 \pm 4.04^{\mathrm{ab}}$ & $9.93 \pm 4.48^{\mathrm{bcd}}$ & $10.29 \pm 3.31^{\mathrm{abc}}$ & $112.353 \pm 53.227^{\mathrm{de}}$ \\
\hline $5 \mathrm{NAA}+5 \mathrm{Kin}$ & $96.98 \pm 1.65^{\mathrm{a}}$ & $3.32 \pm 1.58^{d}$ & $15.47 \pm 3.68^{\mathrm{ab}}$ & $222.167 \pm 92.369^{\text {cde }}$ \\
\hline $5 \mathrm{NAA}+5 \mathrm{BAP}$ & $96.14 \pm 1.84^{\mathrm{a}}$ & $5.25 \pm 1.91^{d}$ & $14.09 \pm 3.41^{\mathrm{abc}}$ & $1073.722 \pm 63.623^{b}$ \\
\hline $52,4-\mathrm{D}+5 \mathrm{Kin}$ & $91.20 \pm 5.05^{\mathrm{ab}}$ & $8.79 \pm 3.05^{\mathrm{cd}}$ & $15.98 \pm 3.46^{a b}$ & $1804.833 \pm 85.304^{a}$ \\
\hline $52,4-\mathrm{D}+5 \mathrm{BAP}$ & $92.90 \pm 3.14^{\mathrm{a}}$ & $7.09 \pm 3.14^{d}$ & $11.73 \pm 2.90^{\mathrm{abc}}$ & $342.063 \pm 179.899^{b-e}$ \\
\hline
\end{tabular}

In each column, different letters indicate a significant difference $(P \leq 5 \%)$ according to Duncan's Multiple-Range Tests (DMRTs)

\section{Experiment 2: the effect of benomyl inclusion in the culture medium on the contamination and growth of explants} In this experiment, the effect of disinfection methods and the inclusion of benomyl in the culture medium on the explant contamination and viability were assessed. The percentage of bacterial contamination, and viable and browning explants were significantly influenced by the disinfection method, PGRs combination, and their interaction. The percentage of explant browning in the medium containing NAA was higher than that of the medium supplemented with 2,4-D, while the explant viability in the media containing 2,4-D was higher than those containing NAA. Furthermore, explant viability influenced by cytokinin type, so in both 2,4-D and NAA containing media, BAP improved the explant viability as compared to kinetin (Fig. 1). As a result, the maximum and minimum explant viability was observed in the medium supplemented with $1 \mathrm{mg} / \mathrm{L}$ 2,4-D + $1 \mathrm{mg} / \mathrm{L}$ BAP and $1 \mathrm{mg} / \mathrm{L} \mathrm{NAA}+1 \mathrm{mg} / \mathrm{L}$ Kin, respectively. Inclusion of benomyl (100 and $500 \mathrm{mg} / \mathrm{L})$ in the culture medium

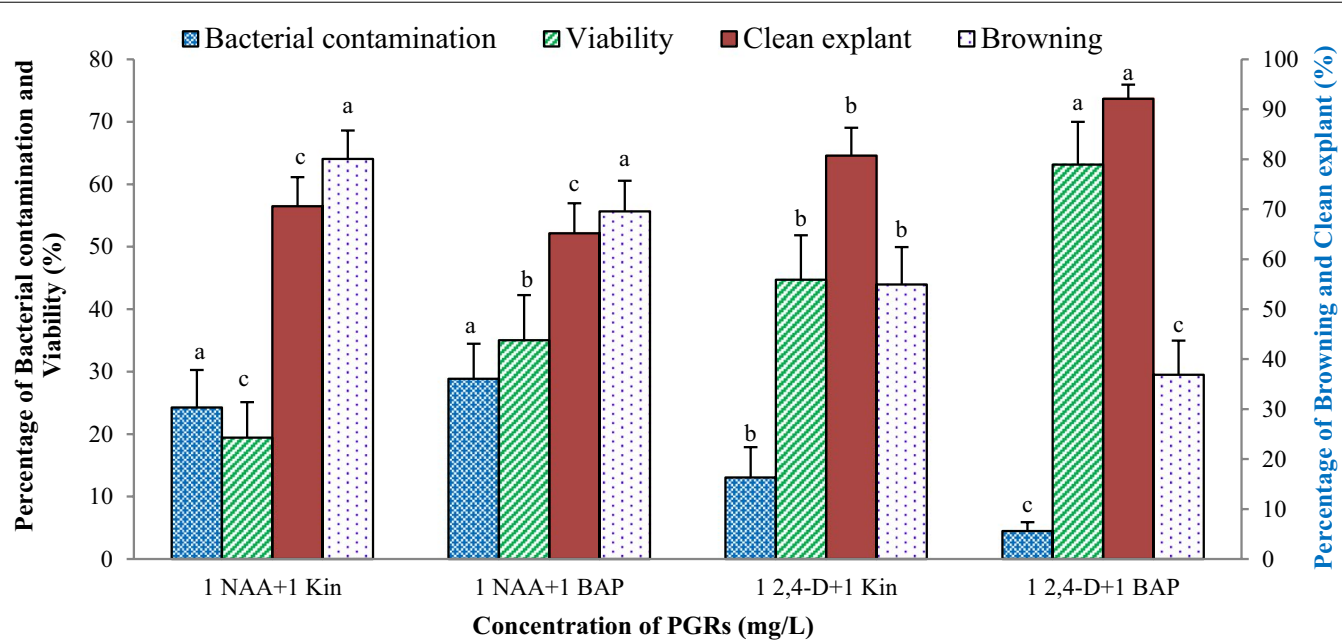

Fig. 1 The effect of plant growth regulators on in vitro responses of $M$. azedarach L. leaf explants in the culture media containing benomyl (Experiment 2). Bars with different letters indicate a significant difference $(P \leq 5 \%)$ according to Duncan's Multiple-Range Tests (DMRTs) 


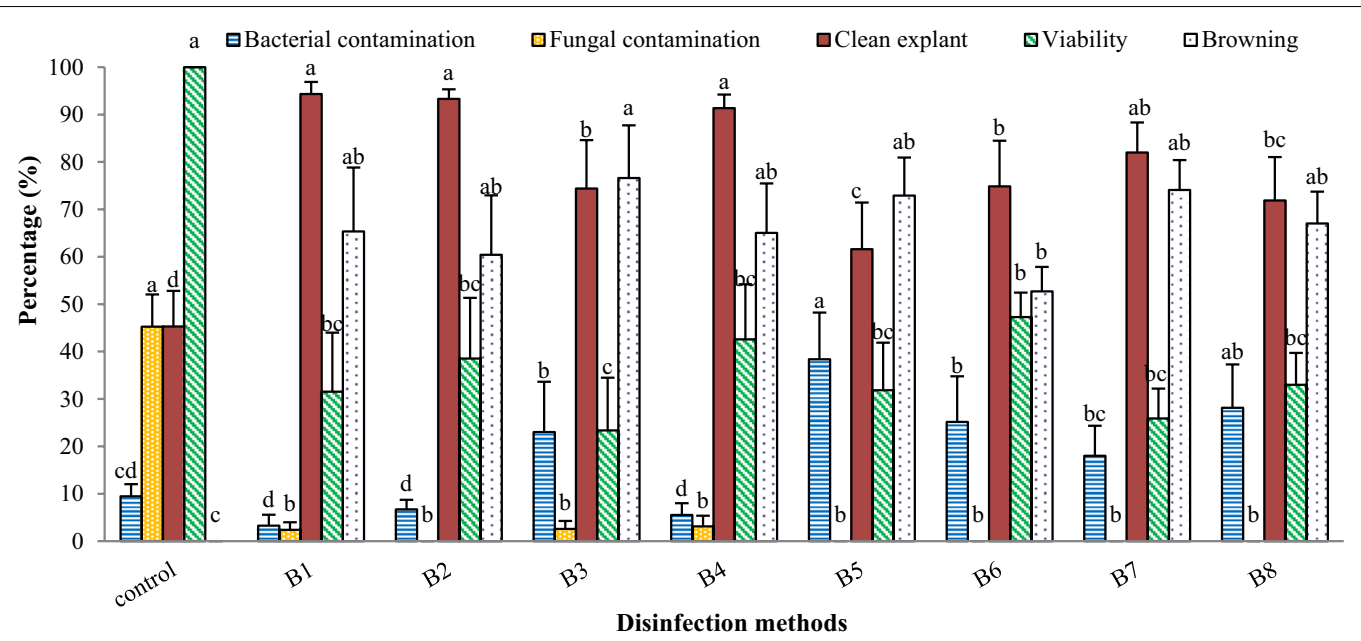

Fig. 2 The effect of different disinfection methods and inclusion of benomyl in culture medium on the bacterial contamination and in vitro response of $M$. azedarach $L$. leaf explants. Bars with different letters indicate a significant difference $(P \leq 5 \%)$ according to Duncan's Multiple-Range Tests (DMRTs)

composition significantly reduced the percentage of fungal contamination in $M$. azedarach L. leaf explant cultures. So, the percentage of viable explants and fungal contamination in the control method were higher than the others. Disinfection methods $B_{1}$ and $B_{5}$ showed the lowest and highest bacterial contamination (\%), respectively (Fig. 2). In this experiment, the callus induction only obtained from the explants disinfected with the method $\mathrm{B}_{4}$ and cultured on the MS medium supplemented with $1 \mathrm{mg} / \mathrm{L} \mathrm{NAA}+1 \mathrm{mg} / \mathrm{L}$ BAP and $1 \mathrm{mg} / \mathrm{L}$ 2,4-D + $1 \mathrm{mg} / \mathrm{L}$ Kin or BAP.

\section{Total phenolic content (TPC), total flavonoid content (TFC) and Anthocyanin (AC)}

Spectrophotometric assay of the secondary metabolites content in the $M$. azedarach L. calli obtained from different PGRs combinations (Additional file 1: Fig. S3) indicated that the amount of TPC, TFC, and AC were significantly influenced by the PGRs (Additional file 1: Table S4). According to the results, TPC in the methanolic extract was varied from 0.001 to $0.109 \mathrm{mg} \mathrm{GAE} / \mathrm{g}$ $\mathrm{FW}$ in $5 \mathrm{mg} / \mathrm{L} \mathrm{NAA}+5 \mathrm{mg} / \mathrm{L}$ Kin and $3 \mathrm{mg} / \mathrm{L} \mathrm{2,4-D}$ $+3 \mathrm{mg} / \mathrm{L}$ BAP treatments, respectively. The highest amount of TFC was obtained in $3 \mathrm{mg} / \mathrm{L} 2,4-\mathrm{D}+3 \mathrm{mg} / \mathrm{L}$ BAP (193.051 mg QE/g FW) treatment, while the lowest value was observed in $5 \mathrm{mg} / \mathrm{L}$ NAA $+1 \mathrm{mg} / \mathrm{L}$ Kin and $5 \mathrm{mg} / \mathrm{L} \mathrm{2,4-D} \mathrm{+5} \mathrm{mg/L} \mathrm{Kin} \mathrm{(58.583} \mathrm{and} 64.638 \mathrm{mg}$ $\mathrm{QE} / \mathrm{g}$ FW, respectively) treatments. The highest and lowest amount of anthocyanin (AC), were obtained from the calli grown on the MS medium supplemented with $3 \mathrm{mg} / \mathrm{L} 2,4-\mathrm{D}+1 \mathrm{mg} / \mathrm{L}$ BAP or $3 \mathrm{mg} / \mathrm{L}$ Kin and $3 \mathrm{mg} / \mathrm{L}$ NAA $+3 \mathrm{mg} / \mathrm{L}$ BAP, respectively (Table 3 ).
As shown in Table 3, increasing the concentration of 2,4-D from 1 to $3 \mathrm{mg} / \mathrm{L}$ significantly increased the amount of TPC, TFC, and AC contents. After that, increasing the 2,4-D concentration from 3 to $5 \mathrm{mg} / \mathrm{L}$ significantly decreased the production and accumulation of these secondary metabolites in the callus cultures of $M$. azedarach L. (Table 3). However, these increase and decreases were varied depending on the type and concentration of cytokinin. For instance, increasing the concentration of 2,4-D from 3 to $5 \mathrm{mg} / \mathrm{L}$ in the medium containing $5 \mathrm{mg} / \mathrm{L}$ Kin or BAP significantly decreased the AC content, but this reduction was not statistically significant in the medium containing $1 \mathrm{mg} / \mathrm{L}$ Kin or BAP (Table 3). On the other hand, increasing the 2,4-D concentration from 3 to $5 \mathrm{mg} / \mathrm{L}$ significantly reduced the TPC and AC contents of the callus cells in both media containing 1 and $5 \mathrm{mg} / \mathrm{L}$ of Kin or BAP. Furthermore, the amount of TFC in the callus cells grown on the medium containing $5 \mathrm{mg} / \mathrm{L}$ 2,4$\mathrm{D}+5 \mathrm{mg} / \mathrm{L}$ Kin or BAP was significantly lower than that of containing $5 \mathrm{mg} / \mathrm{L}$ 2,4-D $+1 \mathrm{mg} / \mathrm{L}$ Kin or BAP. While, there were no significant differences between 1,3 , and $5 \mathrm{mg} / \mathrm{L}$ concentrations of Kin or BAP in the media containing $5 \mathrm{mg} / \mathrm{L}$ NAA (Table 3).

\section{Rutin, quercetin and kaempferol content}

The amount of rutin, quercetin and kaempferol in callus cultures were analyzed using HPLC (Additional file 1: Fig. S4a, S4b), and the results indicated that the production and accumulation of these secondary metabolites significantly influenced by both type and concentration of plant growth regulators (Additional file 1: Table S5). So 
Table 3 The effect of plant growth regulators on total phenolic (TPC), Total flavonoid (TFC), and anthocyanin (AC) content in the callus cultures of M. azedarach L.

\begin{tabular}{|c|c|c|c|}
\hline Concentration of PGRs (mg/L) & $\mathrm{TPC}$ (mg GAE/g FW) & TFC (mg QE/g FW) & $\mathrm{AC}(\mu \mathrm{m} / \mathrm{g} \mathrm{FW})$ \\
\hline $1 \mathrm{NAA}+1 \mathrm{KIN}$ & $0.010 \pm 0.005^{\mathrm{fg}}$ & $82.805 \pm 4.545^{b-g}$ & $1.650 \pm 0.170^{\mathrm{bcd}}$ \\
\hline $1 \mathrm{NAA}+1 \mathrm{BAP}$ & $0.021 \pm 0.006^{d-h}$ & $80.402 \pm 11.385^{b-g}$ & $1.508 \pm 0.302^{\mathrm{bcd}}$ \\
\hline $12,4-\mathrm{D}+1 \mathrm{KIN}$ & $0.027 \pm 0.009^{d-g}$ & $67.522 \pm 4.774^{\mathrm{efg}}$ & $1.647 \pm 0.042^{\mathrm{bcd}}$ \\
\hline $12,4-\mathrm{D}+1 \mathrm{BAP}$ & $0.030 \pm 0.006^{d-g}$ & $68.868 \pm 5.132^{d-g}$ & $1.111 \pm 0.208^{\mathrm{cd}}$ \\
\hline $3 \mathrm{NAA}+1 \mathrm{KIN}$ & $0.026 \pm 0.007^{d-g}$ & $66.465 \pm 10.599^{f g}$ & $1.084 \pm 0.116^{\mathrm{cd}}$ \\
\hline $3 \mathrm{NAA}+1 \mathrm{BAP}$ & $0.051 \pm 0.002^{\mathrm{cd}}$ & $102.509 \pm 13.155^{\mathrm{b}-\mathrm{e}}$ & $1.623 \pm 0.563^{\mathrm{bcd}}$ \\
\hline $3 \mathrm{NAA}+3 \mathrm{KIN}$ & $0.066 \pm 0.011^{b c}$ & $101.644 \pm 17.790^{\mathrm{b}-\mathrm{g}}$ & $1.946 \pm 0.481^{\mathrm{abc}}$ \\
\hline $3 \mathrm{NAA}+3 \mathrm{BAP}$ & $0.022 \pm 0.010^{d-g}$ & $101.836 \pm 14.609^{\mathrm{b}-\mathrm{e}}$ & $0.152 \pm 0.077^{e}$ \\
\hline $32,4-\mathrm{D}+1 \mathrm{KIN}$ & $0.094 \pm 0.007^{\mathrm{ab}}$ & $107.507 \pm 9.145^{b c}$ & $2.458 \pm 0.281^{\mathrm{ab}}$ \\
\hline $32,4-D+1$ BAP & $0.043 \pm 0.002^{c-f}$ & $100.202 \pm 2.888^{b-f}$ & $2.707 \pm 0.386^{a}$ \\
\hline $32,4-\mathrm{D}+3 \mathrm{KIN}$ & $0.090 \pm 0.001^{\mathrm{ab}}$ & $109.237 \pm 6.528^{b}$ & $2.667 \pm 0.545^{\mathrm{a}}$ \\
\hline $32,4-D+3$ BAP & $0.109 \pm 0.007^{\mathrm{a}}$ & $193.051 \pm 16.732^{\mathrm{a}}$ & $2.455 \pm 0.293^{\mathrm{ab}}$ \\
\hline $5 \mathrm{NAA}+1 \mathrm{KIN}$ & $0.013 \pm 0.007^{\mathrm{efg}}$ & $58.583 \pm 13.115^{9}$ & $1.525 \pm 0.417^{\mathrm{bcd}}$ \\
\hline $5 \mathrm{NAA}+1 \mathrm{BAP}$ & $0.012 \pm 0.006^{\mathrm{fg}}$ & $68.291 \pm 9.497^{d-g}$ & $1.6061 \pm 0.102^{\mathrm{bcd}}$ \\
\hline $5 \mathrm{NAA}+5 \mathrm{KIN}$ & $0.001 \pm 0.014^{g}$ & $73.385 \pm 13.732^{c-g}$ & $1.448 \pm 0.288^{\mathrm{cd}}$ \\
\hline $5 \mathrm{NAA}+5 \mathrm{BAP}$ & $0.017 \pm 0.012^{\mathrm{efg}}$ & $69.829 \pm 10.656^{d-g}$ & $1.216 \pm 0.218^{\mathrm{cd}}$ \\
\hline $52,4-\mathrm{D}+1 \mathrm{KIN}$ & $0.046 \pm 0.009^{\text {cde }}$ & $100.875 \pm 2.217^{b-f}$ & $1.865 \pm 0.084^{\mathrm{abc}}$ \\
\hline $52,4-D+1$ BAP & $0.041 \pm 0.016^{c-f}$ & $103.278 \pm 0.254^{\mathrm{bcd}}$ & $1.872 \pm 0.148^{\mathrm{abc}}$ \\
\hline $52,4-\mathrm{D}+5 \mathrm{KIN}$ & $0.022 \pm 0.019^{d-g}$ & $64.639 \pm 11.731^{9}$ & $0.673 \pm 0.139^{\text {de }}$ \\
\hline $52,4-D+5$ BAP & $0.017 \pm 0.008^{\mathrm{efg}}$ & $70.406 \pm 2.141^{d-g}$ & $0.741 \pm 0.255^{\text {de }}$ \\
\hline
\end{tabular}

In each column, different letters indicate a significant difference $(P \leq 5 \%)$ according to Duncan's Multiple-Range Tests (DMRTs)

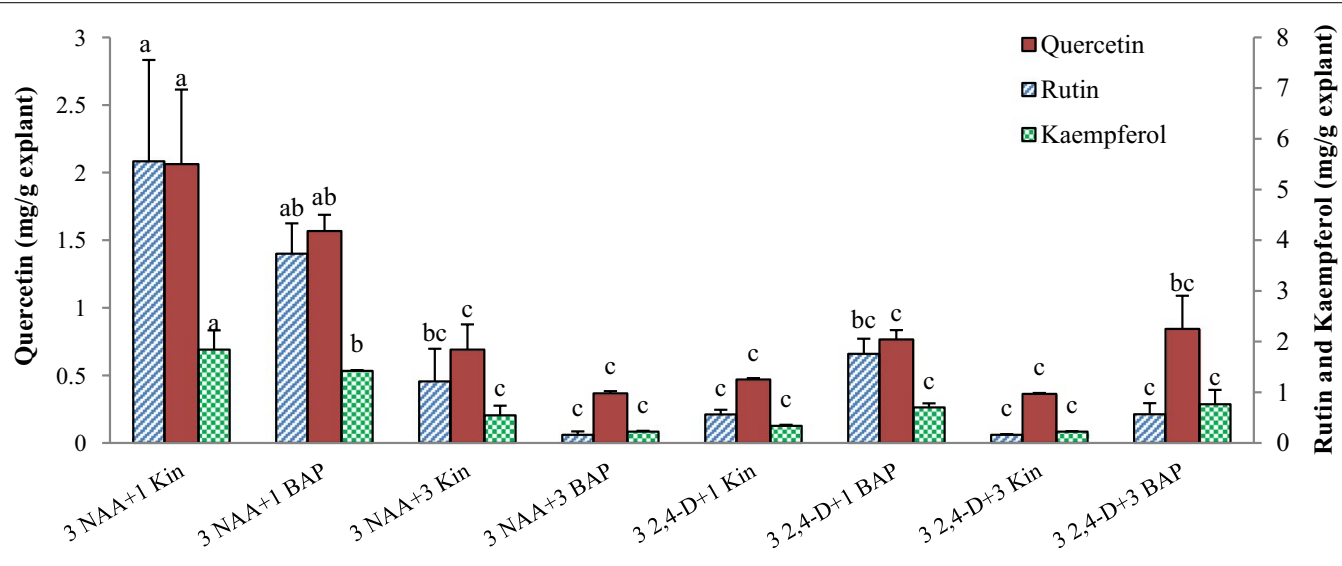

Concenttration of PGRs (mg/L)

Fig. 3 The effect of the plant growth regulators type and concentrations on the amount of rutin, quercetin and kaempferol in the callus cultures of M. azedarach L. Bars with different letters indicate a significant difference $(P \leq 5 \%)$ according to Duncan's Multiple-Range Tests (DMRTs)

that, the highest amount of rutin, quercetin and kaempferol were obtained from the medium supplemented with $3 \mathrm{mg} / \mathrm{L} \mathrm{NAA}+1 \mathrm{mg} / \mathrm{L}$ Kin and $3 \mathrm{mg} / \mathrm{L} \mathrm{NAA}+1 \mathrm{mg} / \mathrm{L}$ BAP treatments (Fig. 3).

\section{Discussion}

Tissue culture techniques play a vital role in plant biotechnology, especially in medicinal plants. Therefore, establishment of successful cultures and overcome to 


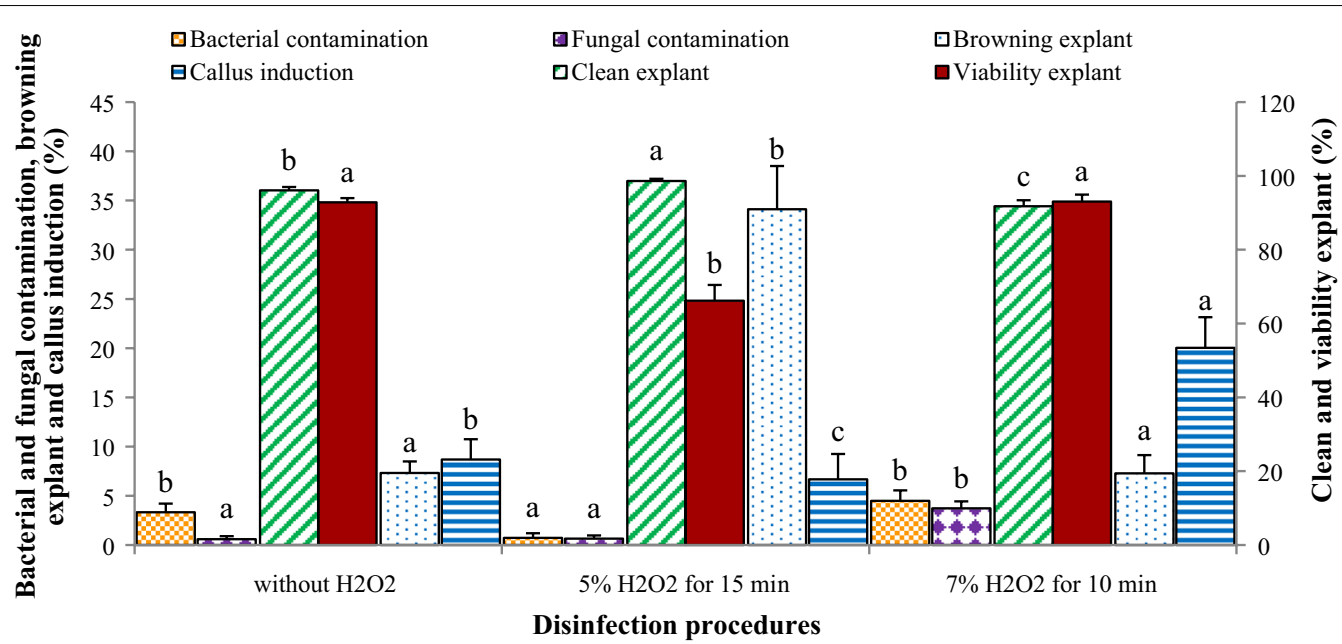

Fig. 4 The effect of $\mathrm{H}_{2} \mathrm{O}_{2}$ inclusion and concentration in disinfection protocol on the M. azedarach L. leaf explants contamination and viability. Bars with different letters indicate a significant difference $(P \leq 5 \%)$ according to Duncan's Multiple-Range Tests (DMRTs)

in vitro contamination requires an efficient protocol for explant disinfection. On the other hand, the preparation and establishment of clean in vitro cultures, especially in woody plants and plant materials prepared from natural habitats is a critical stage in successful plant cell and tissue culture. Disinfection procedures may differ for different plants, depending on their morpho-physiological characteristics (Srivastava et al. 2010). $\mathrm{H}_{2} \mathrm{O}_{2}$ has been reported in a few reports as a potent oxidizing and sterilization agent for the surface disinfection of different plant materials (Mihaljević et al. 2013; Hesami et al. 2019). In our study, utilization of $\mathrm{H}_{2} \mathrm{O}_{2}\left(\mathrm{~A}_{2}, \mathrm{~A}_{3}, \mathrm{~A}_{6}\right.$, and $\mathrm{A}_{7}$ methods) increased the percentage of browning explants (from 7.312 to $20.698 \%$ ) and decreased the explants viability and bacterial contamination (from 92.854 to $79.614 \%$ and 3.336 to $2.599 \%$, respectively) in comparison to the methods without this agent $\left(A_{1}, A_{4}\right.$, and $A_{5}$ methods) (Table 1; Fig. 4). Increasing the concentration of $\mathrm{H}_{2} \mathrm{O}_{2}$ from $5 \%$ (methods $A_{6}$ and $A_{7}$ ) to $7 \%$ (method $A_{2}$ and $A_{3}$ ) significantly decreased the percentage of browning explants (from 34.121 to $7.275 \%$ ) and subsequently increased the percentage of explants viability and callus induction (Table 1; Fig. 4). Curvetto et al. (2006) reported that clean bulblet explants in Lilium improved with increasing the $\mathrm{H}_{2} \mathrm{O}_{2}$ concentration. Accordingly, in Bakhsh et al. (2016) study, the highest contamination-free of gossypium hirsutum L. explants were achieved by utilization of $\mathrm{H}_{2} \mathrm{O}_{2}$. In our study, $M$. azedarach L. leaf explants viability and callus induction in methods including $7 \% \mathrm{H}_{2} \mathrm{O}_{2}$ for $10 \mathrm{~min}$ were 1.5 -times and 3-times, respectively, higher than those of $5 \% \mathrm{H}_{2} \mathrm{O}_{2}$ for $15 \mathrm{~min}$. On the other hand, a higher concentration of $\mathrm{H}_{2} \mathrm{O}_{2}$ with lower exposure duration has no adverse effects on explant viability and callus induction from $M$. azedarach L. leaf explants. Our results are in agreement with Hesami et al. (2019) and Mihaljević et al. (2013) observations in surface sterilization of chrysanthemum and sour cherry, respectively.

In the present study utilization of a two-step disinfection procedure improved the disinfection efficiency and in vitro response of $M$. azedarach L. leaf explants. So that, the clean explants achieved from two agents surface disinfection [pretreatment (step one) with $0.5 \%$ $\mathrm{NaOCl}+3 \mathrm{mg} / \mathrm{L}$ benomyl and treatment (step 2) with $2 \% \mathrm{NaOCl}$ for 12 min (methods $\mathrm{A}_{4}$ and $\mathrm{A}_{5}$ )] was higher than those obtained from one step surface disinfection, in which only $2 \% \mathrm{NaOCl}$ treatment was applied for $12 \mathrm{~min}$ (control treatment) (Table 1). Similarly, in Kozak and Stelmaszczuk (2013) study, $60 \%$ and $80 \%$ clean

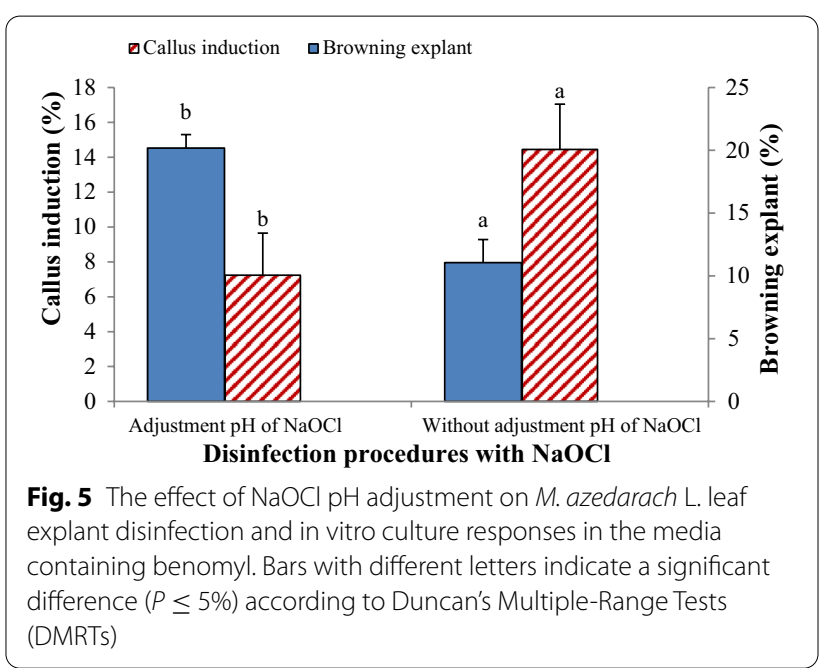


cultures of Allium karataviense explants were obtained, when 4 and $2 \% \mathrm{NaOCl}$ applied for $30 \mathrm{~min}$ followed by $1 \%$ $\mathrm{NaOCl}$ for $15 \mathrm{~min}$, respectively. Furthermore, Sivanesan et al. (2014) reported $100 \%$ clean cultures of Crocus vernus $\mathrm{L}$. corms by utilization of $2 \% \mathrm{NaOCl}$ for $10 \mathrm{~min}$ and $0.01 \% \mathrm{HgCl}_{2}$. Similarly, Siavash Moghaddam et al. (2011) achieved $40 \%$ clean explant with utilization of $1 \mathrm{~g} / \mathrm{L}$ benomyl and $10-15 \%$ clorox $^{\circledR}$, and this value enhanced up to $60 \%$ with the addition of plant preservative mixture (PPM) to the culture medium. Furthermore, in the present study, although adjustment of $\mathrm{NaOCl} \mathrm{pH}$ to $\mathrm{pH}=7$ and 10 significantly reduced the microbial contamination and increased the percentage of clean explants in $M$. azedarach L. in vitro cultures, but adversely influenced the explant viability and callus induction (Table 1; Fig. 5). It has been shown that with reducing the $\mathrm{pH}$ of $\mathrm{NaOCl}$ solution, the chlorine as ${ }^{-} \mathrm{OCl}$ increases, which has been considered as a strong oxidizing agent and most effective on disinfecting functions (Fukuzaki 2006). It seems that these elevated levels of ${ }^{-} \mathrm{OCl}$ in $\mathrm{NaOCl}$ solution with $\mathrm{pH}=7$ and 10 exert cytotoxic effects on $M$. azedarach L. leaf explants; and led to the cell death and reduced in vitro responses of the explants.

Fungicides and bactericides can be useful to proper disinfection and have been used in previous investigations (Sharan et al. 2010). In the aqueous solutions, benomyl breaks down into two compounds, methyle-2-benzimidazolecarbamate and butyl isocyanate, which are toxic to fungi (Pence 2005). The results of the present study showed that, inclusion of benomyl in the culture medium significantly reduced the fungal contamination as compared the control treatment. So, about $80 \%$ clean explant was obtained by addition of 100 or $500 \mathrm{mg} / \mathrm{L}$ benomyl in the culture medium. Our findings are in agreement with Haldeman et al. (1987) observation, who reported 100\% clean cultures of Camellia sinensis shoot tip explants in MS medium supplemented with $1 \mathrm{~g} / \mathrm{L}$ benomyl. Furthermore, Siavash Moghaddam et al. (2011) achieved up to $50 \%$ clean explant in Centella asiatica L. by inclusion $100 \mathrm{mg} / \mathrm{L}$ benomyl in the culture medium composition.

Plants show different in vitro growth response to different types and concentrations of plant growth regulators, especially the combination of auxins and cytokinins (Guo et al. 2009; Firoozi et al. 2019). In the present study, all used PGRs treatment induced callogenesis from M. azedarach L. leaf explants, but with different percentage and callus growth rate. The moderate concentration of NAA or 2,4-D (3 mg/L) combined with 1 or $3 \mathrm{mg} / \mathrm{L} \mathrm{Kin} / \mathrm{BAP}$ resulted in the highest callus induction and growth. So that, increasing the concentration of NAA or 2,4-D up to $5 \mathrm{mg} / \mathrm{L}$ was led to reduced callus induction and growth and the lowest percentage of callus induction obtained in the higher ratios of Aux/Cyt (5 mg/L 2,4-D +1 mg/L
Kin and $5 \mathrm{mg} / \mathrm{L} \mathrm{NAA}+1 \mathrm{mg} / \mathrm{L}$ BAP). These results are in agreement with Firoozi et al. (2019) report in saffron. Nevertheless, Castellar and Iborra (1997) reported the highest callus induction from saffron in vitro cultures on the MS medium supplemented with $10 \mathrm{mg} / \mathrm{L} \mathrm{NAA}$ and $5 \mathrm{mg} / \mathrm{L} \mathrm{BAP}$.

Among the phytochemicals, flavonoids and phenolic compounds are well-known compounds which have antioxidant and anticancer properties may be due to their strong free radical scavenging activity (Tungmunnithum et al. 2018). There has been a growing interest in the improving production of these valuable phytochemicals in the plant cells through in vitro cell culture techniques. Manipulation and optimization of cell culture conditions and medium compositions such as PGRs provide a practical approach for manipulation and improving the cell growth and secondary metabolite production. PGRs act as one of the critical factors influencing the growth and development of plant cells in both whole plant and in vitro cultures (Farjaminezhad et al. 2013; Firoozi et al. 2019). Our results indicated that in vitro production of bioactive secondary metabolites in $M$. azedarach L. callus cultures was significantly influenced by the type and concentrations of auxins and cytokinins. So, the medium

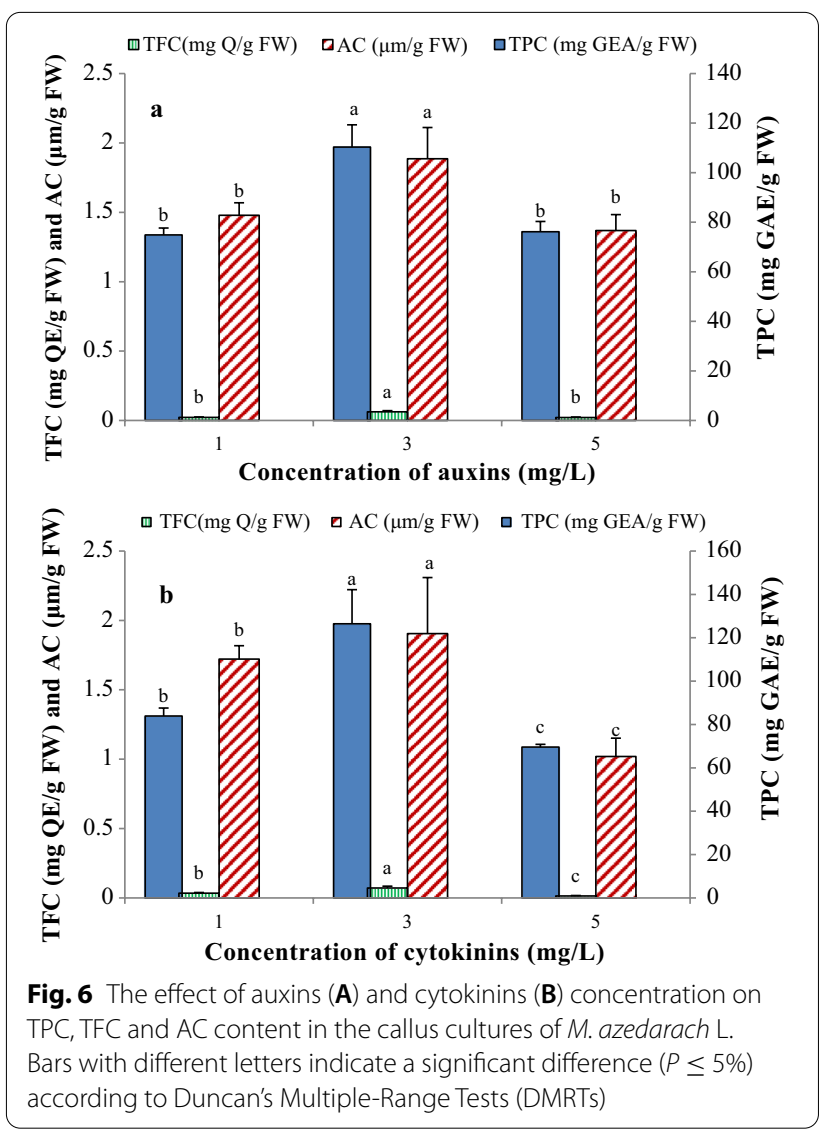


supplemented with moderate concentration $(3 \mathrm{mg} / \mathrm{L})$ of 2,4-D in combination with 1 or $3 \mathrm{mg} / \mathrm{L} \mathrm{BAP} / \mathrm{Kin}$ increased the amount of TPC, TFC, and AC in the callus cultures. So that, the amount of TFC and AC obtained from the calli grown on the medium supplemented with a moderate concentration of 2,4-D was 1.5-2 times higher than those attained from the medium supplemented with other concentrations of 2,4-D or NAA. Regardless of the type of auxins, increasing the auxin concentrations from 1 to 3 were enhanced the amount of TPC, TFC, and AC. In contrast, increasing the auxin concentration from 3 to 5 significantly reduced the TPC, TFC and AC production and accumulation in the $M$. azedarach L. callus cultures (Table 3; Fig. 6A). These results revealed that both type and concentration of auxin play a significant role in the production and accumulation of secondary metabolites in the M. azedarach L. callus cultures. Similarly, Javed et al. (2017) reported that the highest amount of TPC and TFC in Stevia rebaudiana in vitro cultures produced in $2 \mathrm{mg} / \mathrm{L} \mathrm{NAA}+0.5 \mathrm{mg} / \mathrm{L}$ BAP treatment. Where, the lowest TPC was obtained from $2 \mathrm{mg} / \mathrm{L} 2,4-\mathrm{D}+1 \mathrm{mg} / \mathrm{L}$ BAP, and $0.5 \mathrm{mg} / \mathrm{L} 2,4-\mathrm{D}+0.5 \mathrm{mg} / \mathrm{L}$ Kin. Also, the amount of TPC, TFC and AC were increased by increasing the cytokinin concentration from 1 to 3 . In contrast, the amount of these metabolites declined by increasing the cytokinin concentration from 3 to $5 \mathrm{mg} / \mathrm{L}$ (Fig. 6B). Contrariwise, among the treatments assessed in the present study, the calli grown on MS medium containing $3 \mathrm{mg} / \mathrm{L}$ NAA $+1 \mathrm{mg} / \mathrm{L}$ Kin produced the highest amount of rutin, quercetin and kaempferol (5.556, 2.063 and $1.843 \mathrm{mg} / \mathrm{g}$ FW, respectively), which respectively was about $34,5.68$ and 8.23 times higher than those obtained from $3 \mathrm{mg} / \mathrm{L}$ 2,4-D $+3 \mathrm{mg} / \mathrm{L}$ Kin. Furthermore, the calli grown on MS medium supplemented with $3 \mathrm{mg} / \mathrm{L} \mathrm{NAA}+1 \mathrm{mg} / \mathrm{L}$ BAP produced 3.733, 1.568 and $1.423 \mathrm{mg} / \mathrm{g}$ FW of rutin, quercetin and kaempferol, respectively. On the other hand, the production of these secondary metabolites inhibited through 2,4-D. The highest and lowest suppression was occurred in the MS medium containing $3 \mathrm{mg} / \mathrm{L}$ 2,4-D + $3 \mathrm{mg} / \mathrm{L}$ Kin and $3 \mathrm{mg} / \mathrm{L} 2,4-\mathrm{D}+1 \mathrm{mg} / \mathrm{L}$ BAP, respectively. Nair et al. (1992) suggested that the suppression effects of 2,4-D to secondary metabolite production may be attributed to the herbicidal properties of 2,4-D. Furthermore, the results of the present study revealed that with increasing the concentration of cytokinin from 1 to $3 \mathrm{mg} / \mathrm{L}$, the amount of rutin (4.5-times), quercetin (4-times) and kaempferol (3.4-times) in callus cultures were decreased significantly $(\mathrm{p} \leq 5 \%)$. These decreases were varied depending on the auxin type, so that, the amount of decline of rutin, quercetin and kaempferol in the treatments containing NAA were significantly higher than those of the containing 2,4-D. On the other hands, the calli grown on the medium containing Kin produced the higher amount of rutin, quercetin and kaempferol as compared to those on the medium containing BAP, especially at $1 \mathrm{mg} / \mathrm{L}$ level. Farjaminezhad and Garoosi (2021) reported the higher azadirachtin production in Azadirachta indica cell suspension culture in the medium containing $2 \mathrm{mg} / \mathrm{L}$ Kin. In Lian et al. (2002) study on Panax ging, saponin productivity increased when the medium supplemented with a low concentration of cytokinins, but the growth of the cells was not affected. Cytokinins have also been reported to be effective in the induction of artemisinin production in Artemisia missouriensis in vitro cultures (Zia et al. 2007). Zia et al. (2007) reported that inclusion of $8.88 \mu \mathrm{M}$ BAP produced $3.05 \mu \mathrm{g} / \mathrm{g}$ artemisinin in A. absinthium callus cultures, which was higher than that of the media containing NAA or Kin.

In the present study, we established an efficient protocol for disinfection and in vitro culture of $M$. azedarach L. Utilization of two different disinfection agents (first with $\mathrm{H}_{2} \mathrm{O}_{2}$ fallowed by $\mathrm{NaOCl}$ ) improved the sterilization efficiency and in vitro response in $M$. azedarach $\mathrm{L}$. leaf explants. Here we demonstrated the production and accumulation of secondary metabolites including rutin, quercetin and kaempferol in callus cultures of M. azedarach L. Furthermore, the amount of these secondary metabolites influenced by both type and concentration of plant growth regulators. These findings provide a newfound knowledge and the practical approach for biotechnological studies in this medicinal plant and production of valuable secondary metabolites.

\section{Supplementary Information}

The online version contains supplementary material available at https://doi. org/10.1186/s13568-022-01343-8.

Additional file 1: Figure S1. In vitro culture of $M$. azedarach $L_{\text {.; }} A_{1}$ : leaf explants, $B_{1}$ : viable and browning leaf explants after disinfection and in vitro culture, $C_{1}$ : swollen leaf explants and initiation of callus induction on MS medium containing $1 \mathrm{mg} / \mathrm{L} \mathrm{NAA}+1 \mathrm{mg} / \mathrm{L} \mathrm{Kin,} \mathrm{D}_{1}$ and $\mathrm{E}_{1}$ : callus induced on MS medium containing $1 \mathrm{mg} / \mathrm{L} N A A+1 \mathrm{mg} / \mathrm{L}$ BAP and $3 \mathrm{mg} / \mathrm{L} \mathrm{NAA}+1 \mathrm{mg} / \mathrm{L}$ BAP (is embryogenic callus), respectively, $\mathrm{A}_{2}$ and $B_{2}$ : callus initiation and growth on MS $+1 \mathrm{mg} / \mathrm{L} \mathrm{2,4-D}+1 \mathrm{mg} / \mathrm{L}$ Kin, $C_{2}, D_{2}$ and $E_{2}$ : callus growth on MS medium containing $1 \mathrm{mg} / \mathrm{L} 2,4-$ $\mathrm{D}+1 \mathrm{mg} / \mathrm{L} \mathrm{Kin,} 1 \mathrm{mg} / \mathrm{L} \mathrm{NAA}+1 \mathrm{mg} / \mathrm{L}$ Kin and $3 \mathrm{mg} / \mathrm{L} 2,4-\mathrm{D}+3 \mathrm{mg} / \mathrm{L}$ $B A P$, respectively. Figure $\mathbf{S 2}$. In vitro culture of $M$. azedarach $L_{\text {.; }} A_{1}$ : callus induction on MS medium containing $3 \mathrm{mg} / \mathrm{L} N A A+1 \mathrm{mg} / \mathrm{L}$ Kin containing green cells in callus and $B_{1}: 3 \mathrm{mg} / \mathrm{L} \mathrm{NAA}+1 \mathrm{mg} / \mathrm{L}$ BAP containing green and globular shape spots in callus (are embryogenic callus), $C_{1}$ : embryogenic callus that have taken root, $A_{2}$ : globular and torpedo shape embryos, $B_{2}$ : globular embryos under a stereoscope and $C_{2}$ : torpedo shape embryos under a stereoscope. Figure S3. In vitro culture of $M$. azedarach $L$.; Callus growth on $M S+A_{1}: 1 \mathrm{mg} / \mathrm{L} \mathrm{NAA}+1 \mathrm{mg} / \mathrm{L}$ Kin, $B_{1}: 1 \mathrm{mg} / \mathrm{L} \mathrm{NAA}+1 \mathrm{mg} / \mathrm{L}$ BAP, $C_{1}: 1 \mathrm{mg} / \mathrm{L} 2,4-D+1 \mathrm{mg} / \mathrm{L}$ Kin, $D_{1}: 1 \mathrm{mg} / \mathrm{L}$ 2,4-D + $1 \mathrm{mg} / \mathrm{LBAP}, \mathrm{A}_{2}: 3 \mathrm{mg} / \mathrm{L} \mathrm{NAA}+1 \mathrm{mg} / \mathrm{L}$ Kin, $B_{2}: 3 \mathrm{mg} / \mathrm{L} \mathrm{NAA}+1 \mathrm{mg} / \mathrm{LBAP}, \mathrm{C}_{2}: 3 \mathrm{mg} / \mathrm{L} \mathrm{NAA}+3 \mathrm{mg} / \mathrm{L} \mathrm{Kin}$, $\mathrm{D}_{2}: 3 \mathrm{mg} / \mathrm{L} \mathrm{NAA}+3 \mathrm{mg} / \mathrm{L} \mathrm{BAP}, \mathrm{A}_{3}: 3 \mathrm{mg} / \mathrm{L} 2,4-\mathrm{D}+1 \mathrm{mg} / \mathrm{L} \mathrm{Kin}$, $B_{3}: 3 \mathrm{mg} / \mathrm{L} 2,4-D+1 \mathrm{mg} / \mathrm{L} \mathrm{BAP}, C_{3}: 3 \mathrm{mg} / \mathrm{L} \mathrm{2,4-D}+3 \mathrm{mg} / \mathrm{L} \mathrm{Kin}$, 
$\mathrm{D}_{3}: 3 \mathrm{mg} / \mathrm{L}$ 2,4-D $+3 \mathrm{mg} / \mathrm{L} \mathrm{BAP}, \mathrm{A}_{4}: 5 \mathrm{mg} / \mathrm{L} \mathrm{NAA}+1 \mathrm{mg} / \mathrm{L} \mathrm{Kin,} \mathrm{B}_{4}:$ $5 \mathrm{mg} / \mathrm{L} \mathrm{NAA}+1 \mathrm{mg} / \mathrm{L} B A P, C_{4}: 5 \mathrm{mg} / \mathrm{L} \mathrm{NAA}+5 \mathrm{mg} / \mathrm{L} \mathrm{Kin}, \mathrm{D}_{4}: 5 \mathrm{mg} / \mathrm{L}$ $\mathrm{NAA}+5 \mathrm{mg} / \mathrm{L} \mathrm{BAP}, \mathrm{A}_{5}: 5 \mathrm{mg} / \mathrm{L} 2,4-\mathrm{D}+1 \mathrm{mg} / \mathrm{L} \mathrm{Kin}, \mathrm{B}_{5}: 5 \mathrm{mg} / \mathrm{L}$ 2,4-D + $1 \mathrm{mg} / \mathrm{L}$ BAP, $\mathrm{C}_{5}: 5 \mathrm{mg} / \mathrm{L}$ 2,4-D + $5 \mathrm{mg} / \mathrm{L} \mathrm{Kin,} \mathrm{D}_{5}: 5 \mathrm{mg} / \mathrm{L} 2,4$ $D+5 \mathrm{mg} / \mathrm{L}$ BAP, respectively. Figure $\mathrm{S4}$. HPLC chromatogram of rutin, quercetin and kaempferol in the standard mixture $(\mathbf{A})$ and $M$. azedarach $\mathrm{L}$. calli grown on the MS medium containing $3 \mathrm{mg} / \mathrm{L} \mathrm{NAA}+3 \mathrm{mg} / \mathrm{L} \mathrm{Kin} \mathrm{(B).}$ Table S1. Different disinfection methods used in experiment 1 for sterilization of M. azedarach L. leaf explants. Table S2. Different disinfection methods and inclusion of benomyl in culture medium used in experiment 2 for sterilization of M. azedarach L. leaf explants. Table S3. The effect of different disinfection methods on disinfection indices of leaf explants in M. azedarach L. (Experiment 1). Table S4. Effect of PGRs treatment on total flavonoid, total phenol and anthocyanin contents in $M$. azedarach L. calli. Table S5. Effect of PGRs treatment on rutin, quercetin and kaempferol in M. azedarach L. by HPLC analysis.

\section{Acknowledgements}

Not applicable.

\section{Authors' contributions}

All authors contributed to the study conception and design. NZ and RA supervised the research. Material preparation, data collection and analysis were performed by FA, NZ and PS, FA wrote the first draft of the manuscript and all authors reviewed and commented on the manuscript. All authors read and approved the final manuscript.

\section{Funding}

This work was supported by the University of Mohaghegh Ardabili under a Grant Number (51-1796, 1395.08.03).

\section{Availability of data and materials}

All data generated or analyzed during this study are included in this published article.

\section{Declarations}

\section{Ethics approval and consent to participate}

This article does not contain any studies with human participants or animals performed by any of the authors.

\section{Consent for publication}

The authors give consent for the publication of the manuscript to the AMB express.

\section{Competing interests}

The authors declare that they have no knowledge of competing interests.

Received: 13 August 2021 Accepted: 1 January 2022

Published online: 10 January 2022

\section{References}

Al-Farsi M, Alsalvar C, Morris A, Baron M, Shadih F (2005) Comparison of antioxidant activity, anthocyanins, carotenoids and phenolics of three native fresh and sun-dried date (Phoenix dactylifera L.) varieties grown in Oman. J Agric Food Chem 53:7592-7599. https://doi.org/10.1021/jf050579q

Anjum S, Abbasi BH, Hano C (2017) Trends in accumulation of pharmacologically important antioxidant-secondary metabolites in callus cultures of Linum usitatissimum L. Plant Cell Tissue Organ Cult 129:73-227. https:// doi.org/10.1007/s11240-016-1158-3

Asghari Zakaria R, Haghighat Hour M, Zare N (2011) Callus production and regeneration of the medicinal plant Papaver orientale. Afr J Biotechnol 10:11152-11156. https://doi.org/10.5897/AJB11.204

Assareh MH, Sardabi H (2005) Macropropagation and micropropagation of Ziziphus spina-christi. Pesqui Agropecu Bras 40:459-465. https://doi.org/ 10.1590/50100-204X2005000500006
Bakhsh A, Anayol E, Sancak C, Ozcan S (2016) An efficient and cost effective sterilizing method with least microbial contamination and maximum germination ratio for in vitro cotton (Gossypium hirsutum L.) culture. J Anim Plant Sci 26:868-873

Castellar MR, Iborra JL (1997) Callus induction from explants of Crocus sativus L. J Plant Biochem Biot 6:97-100. https://doi.org/10.22364/eeb.14.25

Colgecen H, Koca U, Toker G (2011) Influence of different sterilization methods on callus initiation and production of pigmented callus in Arnebia densiflora Ledeb. Turk J Biol 35:513-520. https://doi.org/10.3906/biy-0911-161

Coria C, Almiron W, Valladares G, Carpinella C, Ludueña F, Defago M, Palacios $S$ (2008) Larvicide and oviposition deterrent effects of fruit and leaf extracts from Melia azedarach L. on Aedes aegypti (L.) (Diptera: Culicidae). Bioresour Technol 99:3066-3070. https://doi.org/10.1016/j.biortech.2007. 06.012

Curvetto N, Marinangeli P, Mockel G (2006) Hydrogen peroxide in micropropagation of Lilium. A comparison with a traditional methodology. Biocell 30:497-500

Farjaminezhad R, Garoosi G (2021) Improvement and prediction of secondary metabolites production under yeast extract elicitation of Azadirachta indica cell suspension culture using response surface methodology. AMB Expr 11:43. https://doi.org/10.1186/s13568-021-01203-x

Farjaminezhad R, Zare N, Asghari-Zakaria R, Farjaminezhad M (2013) Establishment and optimization of cell growth in suspension culture of Papaver bracteatum: a biotechnology approach for thebaine production. Turk J Biol 37:689-697. https://doi.org/10.3906/biy-1304-54

Firoozi B, Zare N, Sofalian O, Sheikhzade-Mosadegh P (2019) In vitro indirect somatic embryogenesis and secondary metabolites production in the saffron: emphasis on ultrasound and plant growth regulators. Tarim Biliml Derg 25:1-10. https://doi.org/10.15832/ankutbd.538973

Fukuzaki S (2006) Mechanisms of actions of sodium hypochlorite in cleaning and disinfection processes. Biocontrol Sci 11:147-157. https://doi.org/10. 4265/bio.11.147

Ghaffoor A, Bahar Shah G, Waseem K (2003) In vitro response of potato (Solanum tuberosum L.) to various growth regulators. Biotechnol 2:191-197. https://doi.org/10.3923/biotech.2003.191.197

Guo X, Fu X, Zang D, Ma Y (2009) Effect of auxin treatments, cutting's collection date and initial characteristics on Paeonia 'Yang Fei Chu Yu' cutting propagation. Sci Hortic 119:177-181. https://doi.org/10.1016/j.scienta. 2008.07.022

Haida Z, Syahida A, Ariff SM, Mahmood Maziah M, Hakiman M (2019) Factors affecting cell biomass and flavonoid production of Ficus deltoidea var. kunstleri in Cell suspension culture system. Sci Rep 9:9533. https://doi. org/10.1038/s41598-019-46042-w

Haldeman JH, Thomas RL, McKamy DL (1987) Use of benomyl and rifampicin for in vitro shoot tip culture of Camellia sinensis and C. japonica. Hortic Sci 22:306-307

Hesami M, Naderi R, Tohidfar M (2019) Modeling and optimizing in vitro sterilization of chrysanthemum via Multilayer Perceptron-Non-dominated Sorting Genetic Algorithm-II (MLP-NSGAII). Front plant sci 10:282. https:// doi.org/10.3389/fpls.2019.00282

Javed R, Yucesan B, Zia M, Gurel E (2017) Differential effects of plant growth regulators on physiology, steviol glycosides content, and antioxidant capacity in micropropagated tissues of Stevia rebaudiana. Biologia 72(10):1156-1165. https://doi.org/10.1515/biolog-2017-0133

Kozak D, Stelmaszczuk M (2013) Comparison of Allium aflatunense B. Fedtsch. 'Purple Sensation' and Allium karataviense Regel. 'Ivory Queen' regenerative capabilities in tissue culture. Acta Sci Pol Hortoru 12:197-213

Lian ML, Chakrabarty D, Paek KY (2002) Effect of plant growth regulators and medium composition on cell growth and saponin production during cell-suspension culture of mountain ginseng (Panax ginseng C.A. mayer). J Plant Biol 45:201-206. https://doi.org/10.1007/BF03030360

Mihaljević I, Dugalić K, Tomaš V, Viljevac M, Pranjić A, Cmelik Z, Puškar B, Jurković Z (2013) In vitro sterilization procedures for micropropagation of 'Oblačinska' sour cherry. J Agric Sci 58:117-126. https://doi.org/10.2298/ JAS1302117M

Murashige T, Skoog F (1962) A revised medium for rapid growth and bio assay with tobacco tissue cultures. Physiol Plant 15:473-497. https://doi.org/10. 1111/j.1399-3054.1962.tb08052.x

Nair AJ, Sudhakaran PR, Madhusudanan JR, Ramakrishna SV (1992) Berberine synthesis by callus and cell suspension cultures of Coscinium fenestratum. Plant Cell Tissue Organ Cult 29:7-10. https://doi.org/10.1007/BF00036139 
Pence VC (2005) In vitro collecting (IVG). 1. The effect of collecting method and antimicrobial agents on contamination in temperate and tropical collections. In Vitro Cell Dev 41:324-332. https://doi.org/10.1079/IVP2004629

Prochazkova D, Bousova I, Wilhelmova N (2011) Antioxidant and prooxidant properties of flavonoids. Fitoterapia 82:513-523. https://doi.org/10.1016/j. fitote.2011.01.018

Sharan M, Dhumne IL, Sharon M (2010) Micropropagation of Chlorophytum borivilliens through direct organogenesis. Adv Appl Sci Res 1:41-46

Shubhangi K, Kirti S, Sofiya M, Suchita G (2017) Quantitative estimation of total phenolics and flavonoids in Soymida febrifuga leaves. Am J Phytomed Clin Ther 5:20

Siavash Moghaddam S, Hawa Binti J, Maheran Abdul A, Rusli I (2011) Optimization of an efficient semi-solid culture protocol for sterilization and plant regeneration of Centella asiatica (L.) as a medicinal herb. Molecules 16:8981-8991. https://doi.org/10.3390/molecules16118981

Sivanesan I, Jana S, Jeong RR (2014) In vitro shoot regeneration and microcorm development in Crocus vernus (L.) Hill. Pak J Bot 46:693-697

Srivastava P, Kasoju N, Bora U, Chaturvedi R (2010) Accumulation of betulinic oleanolic, and ursolic acids in in vitro cell cultures of Lantana camara $\mathrm{L}$. and their significant cytotoxic effects on HeLa cell lines. Biotechnol Bioproc E 15:1038-1046. https://doi.org/10.1007/s12257-010-0054-7

Teixeira da Silva JA, Winarto B, Dobránszki J, Zeng S (2015) Disinfection procedures for in vitro propagation of Anthurium. Folia Hortic 27:3-14

Tungmunnithum D, Thongboonyou A, Pholboon A, Yangsabai A (2018) Flavonoids and other phenolic compounds from medicinal plants for pharmaceutical and medical aspects: an overview. Medicines 5:93. https://doi. org/10.3390/medicines5030093

Wagner GJ (1979) Content and vacuole/extravacuole distribution of neutral sugars, free amino acids, and anthocyanin in protoplasts. Plant Physiol 64:88-93. https://doi.org/10.1104/pp.64.1.88

Yalla R, Satyendra M, Nidhi M (2021) Medicinal uses and biological activity of the secondary metabolites of Melia azedarach Linn.: an overview. Plant Cell Biotechnol Mol Biol 22(33-34):106-123

Zare N, Valizadeh M, Tohidfar M, Mohammadi SA, Malboobi MA, Habashi AA (2009) Selection of regenerative genotypes from Iranian alfalfa cultivars. J Food Agric Environ 7:567-572

Zia M, Mannan A, Chaudhary MF (2007) Effect of growth regulators and amino acids on Artemisinin production in the callus of Artemisia absinthium. Pak J Bot 39:799-805

Zu Y, Chunying L, Yujie F, Chunjian Z (2006) Simultaneous determination of catechin, rutin, quercetin kaempferol and isorhamnetin in the extract of sea buckthorn (Hippophae rhamnoides L.) leaves by RP-HPLC with DAD. J Pharmaceut Biomed 41:714-719. https://doi.org/10.1016/j.jpba.2005. 04.052

\section{Publisher's Note}

Springer Nature remains neutral with regard to jurisdictional claims in published maps and institutional affiliations.

\section{Submit your manuscript to a SpringerOpen ${ }^{\circ}$ journal and benefit from:}

- Convenient online submission

- Rigorous peer review

- Open access: articles freely available online

- High visibility within the field

- Retaining the copyright to your article 